\title{
Prospects for using gamification in Industry 4.0
}

\author{
Ana Carla Bittencourt Reis ${ }^{\mathrm{a}}$ (D), Everaldo Silva Júnior ${ }^{\mathrm{a} *}$ (D), Brenda Baumann Gewehr ${ }^{\mathrm{a}}$ (D), \\ Mateus Halbe Torres ${ }^{\mathrm{a}}$ (i) \\ aniversidade de Brasília, Brasília, DF, Brasil \\ *everaldo.s.junior@gmail.com
}

\begin{abstract}
Paper aims: This study aims to analyze the main applications of gamification in the industry, identifying its benefits and challenges, and to understand how game techniques are impacting the formation of engineers. Finally, the main perspectives of the use of gamification in the Industry 4.0 are presented.

Originality: The scientific literature was analyzed to infer practical applications, challenges, benefits and perspectives that can guide the implementation of gamification in Industry 4.0, aiming to help professionals and researchers to take better advantage of this approach and propel this new phase of the industry.
\end{abstract}

Research method: A literature review was conducted on the use of gamification in the industry.

Main findings: In this article, eleven aspects that must be taken into consideration during the application of gamification in the industries were observed. Five perspectives/situations of Gamification use were raised, namely: in the servitization; in learning and training; as a tool to increase intrinsic motivation; introducing new technologies and products; and innovation and flexibility.

Implications for theory and practice: This study systematically brings together the main approaches to gamification and its applications in the current industry scenario. In addition, this work contributes to the process of designing and implementing gamification in the industry.

Keywords

Manufacture. Learning. Application. Literature review. Intrinsic motivation.

How to cite this article: Reis, A. C. B., Silva Júnior, E., Gewehr, B. B., \& Torres, M. H. (2020). Prospects for using gamification in Industry 4.0. Production, 30, e20190094. https://doi.org/10.1590/0103-6513.20190094.

Received: Aug. 24, 2019; Accepted: Mar. 16, 2020.

\section{Introduction}

By analyzing research on the subject of Industry 4.0, it is possible to identify some current issues that industries are facing. Due to the transition to this new industrial paradigm, that involves digital innovation, globalization and change of consuming habits, the industries are going through important changes in the way they interact with their stakeholders, in order to establish new paths to discovery and communication of its brands (Donatiello et al., 2018; Hurst et al., 2019).

One of the observed changes is that manufacturing organizations are increasingly competing by developing integrated product and service offerings, instead of offering only products, thus providing more value to their customers in a process called servitization (Bustinza et al., 2015; Shi et al., 2017; Andrews et al., 2017, 2018).

The changes in the interaction with customers bring along important challenges for the advancement of Industry 4.0, for instance, the collection and use of data which are processed to add more value to customers, because customers may not be willing to share information about their personal processes. (Gebauer \& Friedli, 2005; Hurst et al., 2019). Thus, CEOs face a variety of difficulties in engaging industry stakeholders in decision making (Potente et al., 2013; Hauge et al., 2016). 
This new way of interacting with customers requires greater flexibility, agility, and sophistication of industries. This leads to the necessity for a better qualification of its employees, making the pursuit of worker training solutions essential for production (Müller et al., 2016). Therefore, another important challenge is training employees in industries, since it can take a long time before they reach the desired operational level (Gilotta et al., 2019).

In parallel with the training, industries must focus on motivating and adapting employees to operational changes, because, as Schuldt \& Friedemann (2017) point out, as Industry 4.0 develops, production process structures are getting increasingly machine-dependent, making employees feel excluded from the workflow, emerging a challenge for organizations to develop motivational action plans (Lee et al., 2016; Roh et al., 2016; Korn et al., 2017; Liu et al., 2018).

Creating an environment that improves motivation is a complex process, in a way that the effectiveness of incorporating motivational strategies to align all stakeholders with specific desired goals is a major challenge for today's industries.

Concurrently with the development of Industry 4.0, technological advances increased the use of electronic devices and the Internet in the most varied environments and contexts. The use of games has been strongly influenced by this evolution, becoming increasingly common in people's daily lives and impacting society and industries, which favors the implementation of gamification (Schlemmer \& Marson, 2013; Silva Júnior et al., 2019).

The new generation of employees, customers and students participating in the so-called fourth industrial revolution, commonly referred to as Industry 4.0, grew up using games, whether on computer, smartphones and/or video games, naturally being used to gaming experiences (Schuldt \& Friedemann, 2017).

Universities and industries seek to develop new methodologies and tools for producing, applying and using game techniques, aiming at enhancing both students' and future engineering professionals' learning, better engaging customers with your services and products, and improving employees' working experience in contemporary industry (Markopoulos et al., 2015; liu et al., 2018).

Faced with this scenario of challenges and opportunities related to this fourth era of the industry, the following questions arise: What aspects of Gamification can be used to support lndustry 4.0? What challenges and benefits can applying this approach bring? What is the role of gamification in training engineers? The relevance of these questions is evidenced not only because of the growth in gaming consumption but also as a result of the need to explore the use of motivational approaches to managing current and future market and society challenges.

The motivation for this research is the fact that it is possible to find in the literature several applications of gamification related to current industries, ranging from learning to productive processes (Müller et al., 2015; Korn et al., 2017), but it's still unclear how it can drive Industry 4.0. Thus, it is necessary to elucidate their contribution to help practitioners and researchers to take greater advantage of gaming techniques and propel this new stage of the industry.

This research aims to conduct a literature review on: the key applications, benefits and challenges of using gamification in industries; the implications of this approach on training engineers, especially production engineers, who may take a prominent position in the context of Industry 4.0; the variety of gamification applications in this new industrial era (Baena et al., 2017; Reis et al., 2017). Through this study of the literature, it was possible to propose an integrative model on the perspectives of gamification use in lndustry.

The contribution of this research is to bring from a literature review on industry-related gamification, the actions that can be performed during the process of gamification application. These actions were classified into five perspectives proposed in this study represented by an integrative model contemplating suggestions on how this approach can be applied within each of the presented strategies.

\section{Gamification}

Deterding et al. (2011a) investigated the historical origins of the term gamification in relation to precursors and similar concepts, based on its differentiation from the concepts of Serious Game, Toy and Ludic Design. According to the authors, Gamification is not a joke or a complete game like Toy and Serious Game respectively. They also claim that Ludic Design, as well as Gamification, includes game techniques, but it works as a joke.

Joke refers to participation in a game without the need or intention to learn a concept, while Serious Game, on the other hand, is intended to impart knowledge, being thought for an educational purpose (Tseng et al., 2016). Gamification, in turn, consists of using game-based techniques and mechanisms in a non-game context for the purpose of engaging people, motivating action, promoting learning, and problem solving (Kapp, 2012; Hauge et al., 2016). 
Gamification is not just about adding medals, points and rewards, there are several other game techniques that should be taken into account during the development (Heeter et al., 2011; Sailer et al., 2017). In this research, the term game technique refers to the elements, dynamics, or mechanisms that are commonly used in games.

Therefore, several game techniques can be used in a gamification, such as Avatars, Teammates, Points, Badges, Leaderboards, Narrative, Performance Graphs, Rewards, Voting, Betting, Levels, Quests, Progress Bar, Collaboration, Boss Fights, Content Unlocking, Discussion board, Invitations, Rules, Virtual Shop, Missions, Time limit, Push notifications and Feedback (Sailer et al., 2017; Subhash \& Cudney, 2018; Alhammad \& Moreno, 2018). Each game technique has a different impact on game design and in the specific context of application (Subhash \& Cudney, 2018).

Topic 3 presents the methodology used in this research, detailing how the results were obtained.

\section{Research methodology}

To achieve the research objective, a literature review was conducted using a method adapted from Vieira \& Gomes (2009), Borrego et al. (2014), Reis et al. (2017), and Mariano \& Rocha (2017). These studies were used as a basis because they illustrate literature review procedures related to interdisciplinary fields, such as those investigated in the present research, which goes through several areas related to Industry 4.0 and Gamification. Also, there are similar objectives between this investigation and these works, which in general are related to the synthesis of the literature aiming to identify the context of a theme, the research fronts, and future perspectives.

This method is represented by Figure 1 and is divided into three stages: definition of the research object; selection of the relevant articles to the purpose of the study; and deepening and developing the study.

\section{LITERATURE REVIEW}
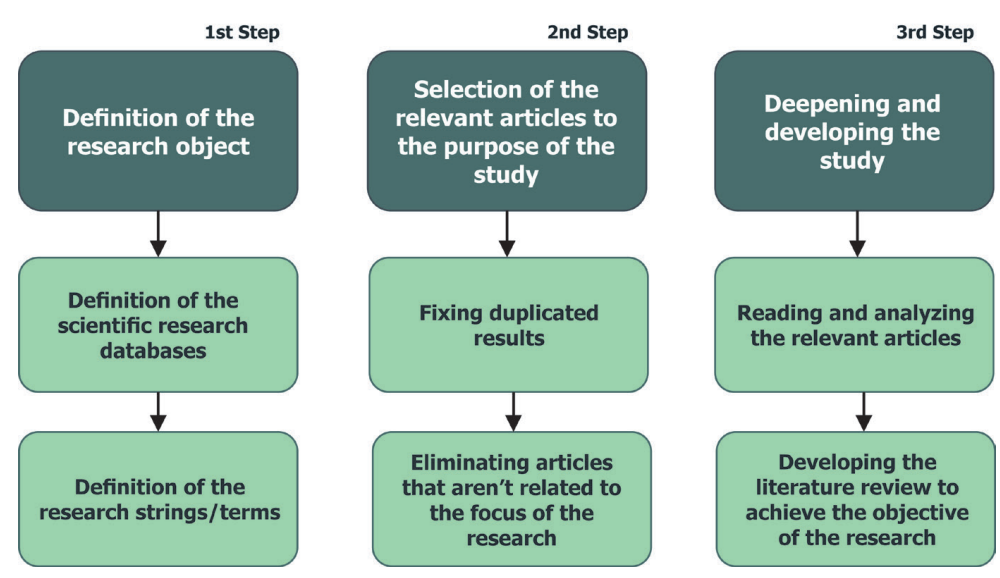

Figure 1. The steps taken during the literature review.

Source: Adapted from Vieira \& Gomes (2009), Borrego et al. (2014), Reis et al. (2017) and Mariano \& Rocha (2017).

In the first stage, based on the research preparation of Mariano \& Rocha (2017) and the works of Borrego et al. (2014) and Vieira \& Gomes (2009), the research databases and strings were defined. The scientific databases chosen were Scopus ${ }^{\circledR}$, Web of Science $\left(\mathrm{WoS}^{\circledR}\right)$ and Scientific Electronic Library Online (SciELO $\left.{ }^{\circledR}\right)$, as they are among the most important scientific databases, and their exclusion could result in loss of relevant studies for a research (Vieira \& Gomes, 2009; Reis et al., 2017; Mariano \& Rocha, 2017). The terms "gamification" AND ("manufactur *" OR "industry") were the strings used, filtering by knowledge areas related to the following themes: Engineering, Management, and Business. Thus, the research returned a total of 247 articles on the subject, being 177 from Scopus ${ }^{\circledast}, 68$ studies from WoS ${ }^{\circledast}$ and 2 from SciELO ${ }^{\circledR}$.

In the second stage, characterized by the selection of the relevant articles to the research objective, duplications of results, articles found in more than two databases, were fixed. This duplication occurs mainly between Scopus ${ }^{\circledast}$ and $\mathrm{WoS}^{\circledast}$ bases, as several studies can be found in both of them. Despite this, many relevant studies 
are present in only one of these bases and should not be disregarded, but analyzed separately according to the methodological procedure adopted (Vieira \& Gomes, 2009; Mariano \& Rocha, 2017).

In the third stage, the 30 articles were analyzed in detail to allow a better understanding of the subject and to detach relevant elements for the current industries, namely: how gamification is being applied in the current industries, focusing on the benefits and difficulties of this application; how game techniques are impacting the training of engineers for industries; and what can be the ways to use gamification in Industry 4.0.

\section{Gamification in industries}

This topic presents the result of the research on the characteristics of gamification applied to industry. The following topics approach how game techniques are being applied across industries, as well as the benefits and challenges encountered in applying these methods.

\subsection{Game techniques and how they are being applied in industries}

Several combinations of game techniques are used during the application of gamification in industries. For example, in the auto industry, we see the application proposed by Korn et al. (2017) in which three designs are presented to gamify the production in automobile industries. All these three projects adopt the Visual Progress game technique, which is applied using different colors so that work processes completed faster than normal are displayed in green, while processes completed more slowly than normal are colored in yellow, orange or red. Errors always result in red views and may have additional consequences, such as the removal of some visual item.

In the fashion industry, Donatiello et al. (2018) present the use of Gamification in a virtual dressing room, called "Fashion lsland". The virtual game allows customers to dress an avatar by selecting clothes and accessories in a relaxing, tranquil and fun virtual environment. Users can also evaluate their choices through a mirror located in the virtual environment.

Liu et al. (2018) feature a gamified smartphone application that is applied to the work experience of employees in an auto industry, providing real-time feedback on their job performance. The app works as a game that tracks and monitors data generated from participants' work processes instead of changing their original work.

In the study by Bennett \& Vijaygopal (2018), Gamification was applied through the Obstacles and Virtual Environment game techniques in an electric car simulation game that allows a person with no driving experience to learn about this vehicle and understand their qualities, aiming to stimulate players' curiosity for this industry.

Roh et al. (2016) present a gamification interface in the bolt-tightening work on the automotive assembly line. When performing a bolt-tightening job, workers can experience gradual goals, receive feedback through an audio-visual mechanism, and have a progress bar. The overall score is presented using the Badges game technique, which gives an epic meaning to the work experience.

There are currently several software gamification applications to engage stakeholders in the servitization process (Andrews et al., 2017). An example of this is the game presented by Andrews et al. (2018), which originated in the adaptation of Bigdeli \& Baines' (2017) servitization model to a board game called Snakes and Ladders. The purpose of this adaptation is to explore the inhibitors and facilitators of servitization.

The study by Müller et al. (2016) presents two Gamification examples used to qualify professionals for manual production tasks, namely: the assembly game and the game system in the assembly workplaces. The first was developed for computers and the second using Kinect technology.

Another example of the application of Gamification in employee training is presented in the work of Kampker et al. (2014). In this study, Gamification is applied during the early phase of industrial production, called Ramp-up, through a board game that uses game techniques like Time Limit, Competition and Points.

The game techniques Goals, Rewards and Collaborative were applied in a task management application with a bottom-up domain, through an online study in which employees were interviewed so that they could decide what, when and how aspects of their work context would be gamified (Lessel et al., 2016).

Fischer's (2017) article addresses a Business Intelligence (BI) system that uses gamification to support the work of its sellers in order to satisfy customers and sell their products. The interaction in the company of the case study is triggered by seller Leaderboards, grating Points and Rewards depending on their performances.

The application of gamification to support knowledge processes in engineering environments is also identified. The article by Hauge et al. (2016) describes a way to capture knowledge in a simulation game to support Product-Service System (PSS). In the example of application given by the authors, among the three case studies 
that were in progress during the research, the task was to decide what requirements a future Product-Service System (PSS) needed to meet in the manufacture of office furniture.

Morêda Neto et al. (2014) and Leite et al. (2016) present, in a case study, the development, implementation, and evaluation of a gamified web system for construction industries. The system is made up of communication panels, used to display weekly planning information, job site performance appraisals, and team rankings.

In the case study presented by Cerezo-Narváez et al. (2019), the Lego ${ }^{\circledR}$ Serious Play ${ }^{\circledR}$ approach is applied as a facilitating tool for introducing skills in Industrial Risk Prevention to engineering students, which can be used to train employees in industries. This gamified approach is based on a number of proposed challenges involving risk assessments, accident investigations, and others.

Lithoxoidou et al. (2020) present a case study in which a social collaboration platform was introduced into an industrial environment to enhance employee interaction, creating a social community in which users can share concerns, ideas, and knowledge.

Table 1 presents a summary of the main gaming techniques identified after reading the case studies in which Gamification was used, highlighting the application form and the type of industry.

Table 1. Game techniques and how they are being applied in industries.

\begin{tabular}{l} 
Key game techniques identified \\
\hline Rewards, Damage and Rules \\
Avatar. Narrative and Virtual Environment \\
Points, Badges, Achievements and Leaderboard \\
Obstacles and Virtual Environment \\
Badges, Goals, Feedback, Progress Bar and Time \\
Limit. \\
Unpredictability, Milestones and Moderator.
\end{tabular}

Narrative, Rewards, Levels, Quests, Challenges, Goals, Feedback, Experience Points, Avatar, Time Limit, Countdown and Rules.

Time Limit, Competition and Points.

Goals, Rewards and Collaborative

Points and Rewards

Time Limit and Rewards

Points, Badges, Rewards, Ranking, Feedbacks and Rules.

Points, Quests and Teams.

Points, Badges, Levels, Rules, Rewards, Teams, Ranking, Votes and Feedbacks.

Application Form
In viewing employee productivity
Virtual dressing room for clothes and
accessories
Smartphone game app that collects task
data
Simulation game of an electric vehicle
Gamification interface on bolt tightening
work on assembly line
ln adapting a board game that exploits
the inhibitors and facilitators of the
transformation of servitization
ln professional training for manual
assembly tasks
During the Ramp-Up phase of a Product
Task management application with a
bottom-up domain
Business lntelligence (Bl) in sales
processes
Simulation game to support Product-
Service System (PSS)
Gamified Visual Manager
Lego Serious Play ${ }^{\circledR}$ approach for
Prevention

Social Community of shop-floor workers

\begin{tabular}{cc} 
Industry Type & Reference \\
\hline $\begin{array}{c}\text { Automotive } \\
\text { Fashion }\end{array}$ & Korn et al. (2017) \\
Donatiello et al. (2018) \\
Automotive & Liu et al. (2018)
\end{tabular}

Automotive Bennett \& Vijaygopal (2018)

Automotive Roh et al. (2016)

General Andrews et al. (2018)

Manufacturing Müller et al. (2016)

\begin{tabular}{|c|c|}
\hline Automotive & Kampker et al. (2014) \\
\hline General & Lessel et al. (2016) \\
\hline Automotive & Fischer (2017) \\
\hline General & Hauge et al. (2016) \\
\hline $\begin{array}{c}\text { Civil/ } \\
\text { Construction }\end{array}$ & $\begin{array}{l}\text { Morêda Neto et al. (2014) } \\
\text { and Leite et al. (2016) }\end{array}$ \\
\hline General & Cerezo-Narváez et al. (2019) \\
\hline
\end{tabular}

It is notable that, within the sample of practical researches in the studies, the sector in the industry that applied gamification the most was automotive. However, it was possible to find applications of gaming techniques in other types of industrial organizations, such as those working with fashion. The Rewards technique was the one that stood out among the studied applications. Section 4.2 presents the benefits that industries can achieve through gamification.

\subsection{Benefits of using gamification in the industrial midst}

Several benefits were observed as a result of the application of gamification in many different contexts, as shown by the studies analyzed. One of the main benefits of using gamification methods in the industrial midst is the capacity to raise intrinsic motivation. Although extrinsic rewards, like, for instance, an economical compensation, may contribute to increase motivation, it is efficient only in the short-term, not being capable of creating intrinsic and long term motivation (Cameron \& Pierce, 1994; Skinner, 1990). 
The use of gaming methods in non-gaming contexts, referred to as gamification, is being proposed as a solution to improve the engagement and the entire working experience of employees in the long-term (Feltham et al., 2007; Deterding et al., 2011b; Hauge et al., 2015). One of the reasons that may explain gamification's superior potential to motivate employees is the establishment of clear goals and concrete purpose for the developed tasks (Lee et al., 2016).

By being effective in improving intrinsic motivation, gamification is directly beneficial to several other aspects in the industry. An overall improvement in satisfaction with work, performance and productivity can be perceived by applying gamification methods (Kampker et al., 2014; Lee et al., 2016; Roh et al., 2016; liu et al., 2018). These methods also help the industries in providing a more humane and pleasant work experience to machine operators, as well as in improving the efficiency of their learning processes (Kampker et al., 2014; Liu et al., 2018).

The results also point out that Gamification enables a promising and creative business area. For instance, in the fashion industry a virtual reality game called "Fashion lsland" behaves as virtual fitting room, where the objective of the games is to dress an avatar (Donatiello et al., 2018). In that sense, one of the main innovations on which the applicability of gamification can be identified is the use of smart fitting, that allows online buyers to purchase the right clothes without the need to test them physically.

The facilitated transmission of knowledge is another benefit that results from gamification, since this approach can render complex concepts simple, easing the comprehension by the general public (Wang et al., 2015).

Thus, gamification is being largely used to diffuse the concepts related to sustainability, since they are considered to be complex and difficult to comprehend. This usage comes from the need of presenting and communicating benefits of the sustainable manufactured goods, and, in doing so, the game techniques accelerate the raise of awareness on sustainability (Wang et al., 2015; Despeisse, 2018; Paravizo et al., 2018).

Beyond its potential to increase awareness about sustainable production, gamification can also promote abilities and knowledge about leadership related to sustainability in manufacturing, being, therefore, a facilitator of sustainable manufacturing (Despeisse, 2018; Paravizo et al., 2018).

Wang et al. (2015) approach the aspects of Gamification with focus on encouraging people to explore the concepts of sustainable manufacturing. This application model allows communicating the benefits of sustainable manufactured goods and to encourage its consumption by improving the capacity of recognizing such products. The interest in transmitting sustainability as a concept is related to the Industry 4.0, once it aims to create more sustainable processes (Paravizo et al., 2018).

However, gamification is able to contribute in several other ways to industries. The benefits, as well as the elements needed to reach them, are presented in Table 2.

Table 2. Benefits of using gamification in the industrial midst.

\begin{tabular}{|c|c|c|}
\hline Benefits & Game techniques that can be used & Reference \\
\hline $\begin{array}{l}\text { Supports the teaching of new knowledge, increases learning } \\
\text { efficiency in the industry and enables participants to engage in the } \\
\text { learning experience. }\end{array}$ & $\begin{array}{l}\text { Collaboration, Time limit, Competition, Points, } \\
\text { Challenges, Feedbacks and Rewards. }\end{array}$ & $\begin{array}{l}\text { Kampker et al. (2014), Schuldt \& } \\
\text { Friedemann (2017) and } \\
\text { Paravizo et al. (2018) }\end{array}$ \\
\hline $\begin{array}{l}\text { Reduces the risks in the business case by contributing to the } \\
\text { improvement process and generating incentives to act through } \\
\text { accurate forecasting and information. }\end{array}$ & Uninformed & Hurst et al. (2019) \\
\hline $\begin{array}{l}\text { Facilitates and encourage online clothing and accessory purchases } \\
\text { and maintain customer loyalty. }\end{array}$ & Avatar, Narrative and Virtual Environment & Donatiello et al. (2018) \\
\hline $\begin{array}{l}\text { Develops the ability to increase productivity, increase job satisfaction, } \\
\text { increase employee retention, and improve job performance and } \\
\text { efficiency. }\end{array}$ & $\begin{array}{l}\text { Rewards, Goals, Feedback, Points, Badges, } \\
\text { Achievements and Leaderboards }\end{array}$ & $\begin{array}{l}\text { Lee et al. (2016), Lessel et al. } \\
\text { (2016), } \\
\text { Roh et al. (2016), Liu et al. } \\
\text { (2018) and Shyam Nivedhan \& } \\
\text { Priyadarshini (2018) }\end{array}$ \\
\hline $\begin{array}{l}\text { Helps in teaching and understanding complex concepts, simplifies } \\
\text { complex decisions, and enables immersion in complex situations } \\
\text { (such as sustainability concepts). }\end{array}$ & $\begin{array}{l}\text { Rules, Narrative, Collaboration, Powers, Roles, } \\
\text { Performance Meaningful Stories, Teamwork, } \\
\text { Element Limiting, Scenarios, Challenges, } \\
\text { Rewards, Goals and Feedback }\end{array}$ & $\begin{array}{c}\text { Monchatre (2007), } \\
\text { Markopoulos et al. (2015), } \\
\text { Wang et al. (2015), Paravizo et al. } \\
\text { (2018) and Despeisse (2018) }\end{array}$ \\
\hline $\begin{array}{l}\text { Helps improving the engineering process' requirements and can be } \\
\text { used as a facilitating tool for gathering information. }\end{array}$ & $\begin{array}{l}\text { Leaderboards, Points, Rewards, Virtual } \\
\text { Environment, Narratives, Avatars, Rules, Goals, } \\
\text { Feedback and Interactive Processes }\end{array}$ & Fischer (2017) and Shi et al. (2017) \\
\hline $\begin{array}{l}\text { Helps manufacturers and government agencies stimulate mass } \\
\text { market for electric vehicles. }\end{array}$ & Obstacles and Virtual Environment & Bennett \& Vijaygopal (2018) \\
\hline $\begin{array}{l}\text { Facilitates changes in attitude toward a product or activity and } \\
\text { introduces a person to a product or activity in which the individual } \\
\text { has no previous experience. }\end{array}$ & Obstacles, Virtual Environment and Feedback & $\begin{array}{c}\text { Wang et al. (2015) and Bennett \& } \\
\text { Vijaygopal (2018) }\end{array}$ \\
\hline $\begin{array}{l}\text { It helps convince users of the benefits of senvitization, provides } \\
\text { valuable insight into transformation processes, and helps stakeholders } \\
\text { explore the implications of servitization. }\end{array}$ & $\begin{array}{l}\text { Virtual Environment, Narratives, Avatars, } \\
\text { Rules, Goals, Feedback, Interactive Processes, } \\
\text { Unpredictability, Milestones and Moderator }\end{array}$ & $\begin{array}{l}\text { Shi et al. (2017), Andrews et al. } \\
\text { (2017) and Andrews et al. (2018) }\end{array}$ \\
\hline Contributes to the dissemination of lean knowledge (lean principles). & Rules and Supply limit & $\begin{array}{l}\text { Sousa et al. (2016) and } \\
\text { Tseng et al. (2016) }\end{array}$ \\
\hline
\end{tabular}


Table 2 exposes the diversity of benefits that industries can achieve by using the combination of game techniques in their operational and management processes. However, it is known that the implementation of these combinations of gaming techniques in practice may face some challenges.

The study conducted by Schuldt \& Friedemann (2017) presents a survey of the previous conditions that are recommended before a gamification is planned and applied, namely: cost-benefit ratio, voluntary participation, maintaining the workflow, avoiding disturbing factors, data security e selective usage. However, through the present research, some complementary cares that should be taken into consideration for applying this motivational techniques were identified, such as: focusing on the hedonic mechanics of gamification, avoiding game applications that might be considered too easy or too hard for the user, to discard any kind of monetization, and avoiding scoring systems. Section 4.3 details these difficulties.

\subsection{Challenges in the application of gamification methods in industries}

The challenges in applying gaming techniques in the Industry 4.0 should be thoroughly considered in order to succeed. It is paramount that the concept of gamification is intertwined to the process structures, so that the benefits and expected results can be achieved (Schuldt \& Friedemann, 2017).

lt's necessary to interpret whether gamification is the right tool to achieve the company's goal, since it is not adequate to all learning processes and situations (Schuldt \& Friedemann, 2017). The company should also be cautious, applying gamification techniques selectively, once its effects can be lowered by habituation to the tool (Sailer, 2016).

During the design process, it is important to ascertain the perspectives of all stakeholders in order to avoid flaws in the application of gamification. Not involving the workers in the process of implementing the gaming techniques or using these techniques against their interests could compromise the success of the method (Korn et al., 2017).

Utilitarian and hedonic motivations can create conflicts. Therefore, it may be necessary to unbind the utilitarian mechanic in order to provide sustenance to the hedonic mechanic of the gamification (Robson et al., 2016). The utilitarian mechanic is related to rewards whereas the hedonic mechanic is related to pleasure (Shi et al., 2017). Therefore, any attempt to monetize the process should be avoided, since it can draw focus away from the hedonic mechanic. Monetizing could induce unfriendly competition between workers and provoke demotivation in the long run (Dale, 2014).

The lack of motivation and interest can occur when the game is extremely easy or extremely hard. The game ought to be adapted to the reality in which it is being applied and it must keep its graphics updated (Müller et al., 2016). Thus, it is paramount to establish clear goals, incremental goals, progression mechanisms, intermediate and final status, among other techniques able to maintain the employee engaged (Hauge et al., 2015).

Furthermore, the gamification process must not break the learflow or the workflow in a substantial way, so that the gaming techniques don't disturb the users and shift their focus (Günthner et al., 2015; Korn et al., 2017). It is important to have personal data collection being conducted discreetly, so that user acceptance isn't compromised (Niesenhaus, 2014) and feedback mechanisms should be projected to be minimally invasive (Niesenhaus, 2013).

Scoring systems must be avoided because it can cause excessive dependency on the scores presented, which could lead to negative outcomes to intrinsic motivation, what usually would drive the users to internalize experiences (Nicholson, 2012). Having a low score could cause frustration, which prevents the game's objectives from being accomplished (Despeisse, 2018). It's suggested that scoring system is neither the only nor the most important technique applied.

It is fundamental that participation in gamification activities occurs voluntarily, because if these activities are perceived by the employees as "obligatory fun" or as impositions, they may not be accepted by the workers. (Liu et al., 2018).

Given the information above, Figure 2 presents the topics that deserve closer attention when applying gamification in the industrial midst, as identified by the literature review.

The eleven cautions presented in Figure 2 can serve as a starting point for anyone wishing to apply Gamification in an industrial context to ensure the successful application of this approach. Section 5 introduces how Gamification can contribute to the training of future engineers who will work in industries. 


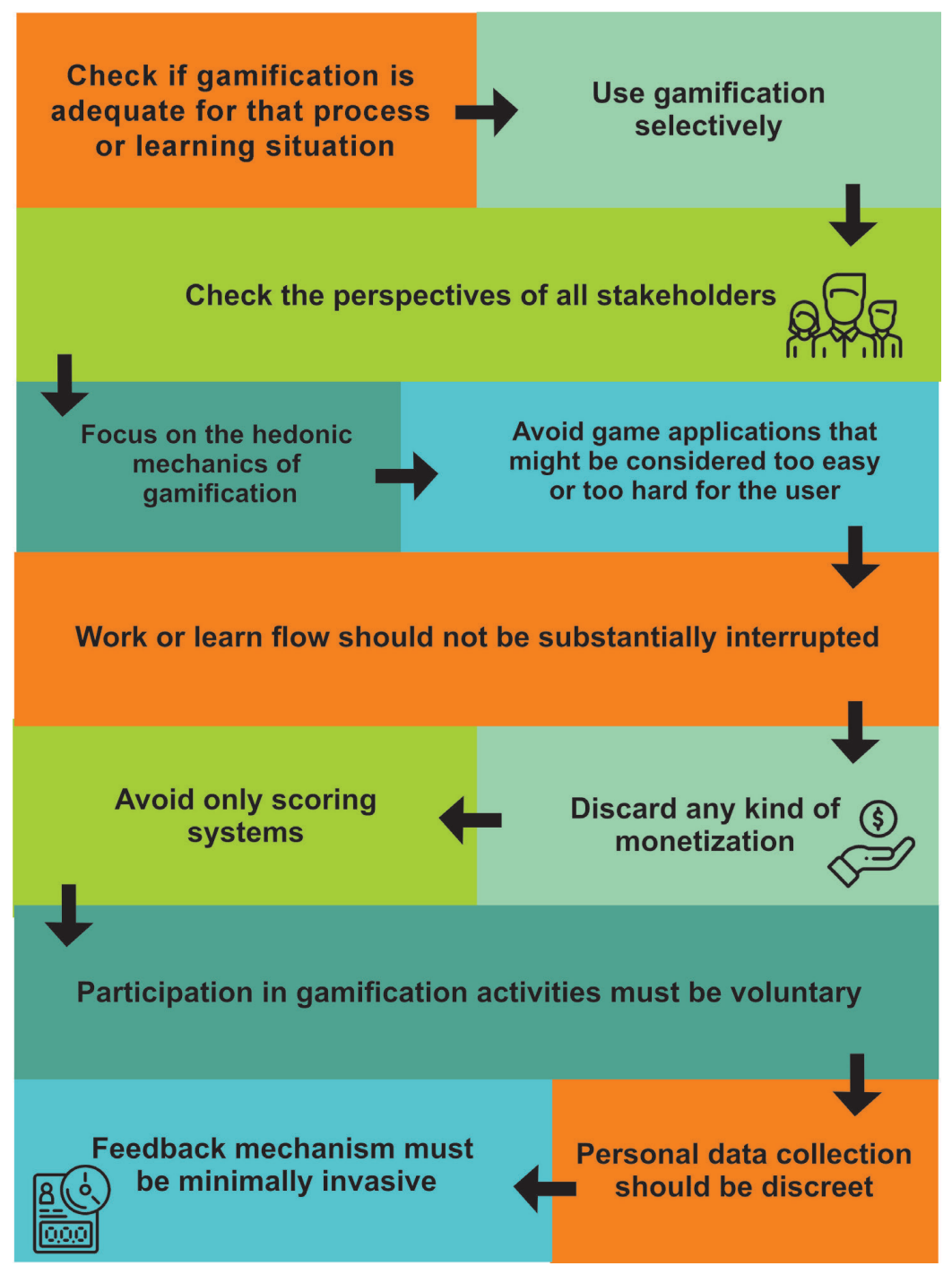

Figure 2. Topics to beware when applying gamification.

\section{Gamification in the formation of engineers for industries}

With the advance of Industry 4.0, a large number of tasks that require human intervention are systematically delegated to modern machines. Such a paradigm shift makes future engineers focus more on acquiring human competencies, such as leadership, since these cannot be assumed by autonomous machines (Panthalookaran, 2018).

The traditional deductive education, in which the teacher introduces the concepts to be studied and the students, passively, try to absorb the knowledge, has been questioned. Alternatively, inductive approaches emphasize that the teaching-learning process should be student-centered, meaning the students should assume greater participation and responsibility for their education (Prince \& Felder, 2006).

The use of active learning approaches has been the subject of many pieces of research and studies to enhance learning in engineering courses. The development of interdisciplinary skills, cooperation, project management, leadership, problem-solving capacity, among other aspects, has been considered essential to compose the training of current engineers (Taajamaa et al., 2013). 
Many of the papers presented highlight that the application of engineering course content in a practical, real-world context brings many benefits to the students (Cano et al., 2006, 2008; Habash \& Suurtamm, 2010; Tran \& Nathan, 2010; Peterson et al., 2011).

Given these facts, it is confirmed the idea perceived in Reis et al. (2017) that the development of engineering students' skills through practical projects involving real-world situations increases their learning and provides better preparation for their professional practice.

In this participative context, oriented to the students' practical activities and greater interation, gamification is considered as a tool to foster many key factors of the students' experience: motivation, application of theoretical knowledge in real world situations, cooperation, pro-activity, experimentation of consequences of their choices, among others aspects (Deshpande \& Huang, 2011; Villagrasa et al., 2014; Müller et al., 2015).

Studies show that the application of games in teaching, whether at a distance or in person, improves the experiences of teachers and students, as it provides a good level of learning in a pleasant and motivating environment (Marinho et al., 2017; Leal et al., 2017).

In general, the use of gamification in the educational context attempts to promote an atmosphere of engagement and motivation similar to those commonly observed in entertainment games (Sousa et al., 2016).

\section{Perspectives on the usage of gamification in the Industry 4.0}

Through the literature review that was conducted, five perspectives on the use of gamification in Industry 4.0 were proposed.

The first proposed perspective was the introduction of new technologies and products, whereas gamification can be of extreme usefulness. Gamification enables immersion in virtual realities, instigating curiosity and a change of attitudes. It can also be used as a mean to introducing new products to clients, enabling said clients to experience the product before purchasing it. The use of gaming techniques in such perspective is also turned to engage and raise awareness about new technologies in the production line.

The second perspective that arises is the need to raise inherent motivation, which derives from concerns in the Industry 4.0 about fomenting the joy that the employee should have when performing his tasks. By the correctly applying gaming techniques, it becomes viable to increase workflow, efficiency, productivity and overall employee satisfaction. The engagement between stakeholders begins to play a crucial role in the market, becoming a competitive criterion.

The usage of gamification approaches in training students and employees unfolds to the third perspective of utilization of gaming techniques in the Industry 4.0. It can turn complex ideas and themes into comprehensible concepts to personal uninstructed in the subject, enabling training times to quicker and more efficient. Human skills as conflict resolution, communication, teamwork and leadership, which are crucial for the Industry 4.0 are boosted by gamification.

The fourth perspective is the ability of enabling servitization, hence the tendency of transformation of industries. Since there are still insecurities attached to the servitization process, gamification could be used as a tool to highlight its benefits and assist with this transformation. Gamification also makes it possible to collect data that is primordial to the success of the transformation.

Gamification for innovation and flexibilization of products and processes is regarded as the fifth perspective. Gaming techniques can be used to engage different stakeholders in product development by eliciting requirements in the different business areas. The Industry 4.0 views flexibility as relevant, since the market is suffering of constant changes, gamification can assist in adapting the employees to those changes in the productive process.

The five different perspectives proposed by this research for applying gamification in the lndustry 4.0 are shown in the integrated model (Figure 3).

The perspectives presented in Figure 3 reveal a way to boost Industry 4.0, in a way that society and industries can adapt to the changes coming from this new world age. Figure 3 also presents some other elements involved, represented by squares, which are examples of how Gamification can be applied within each of the five perspectives proposed in this study. 


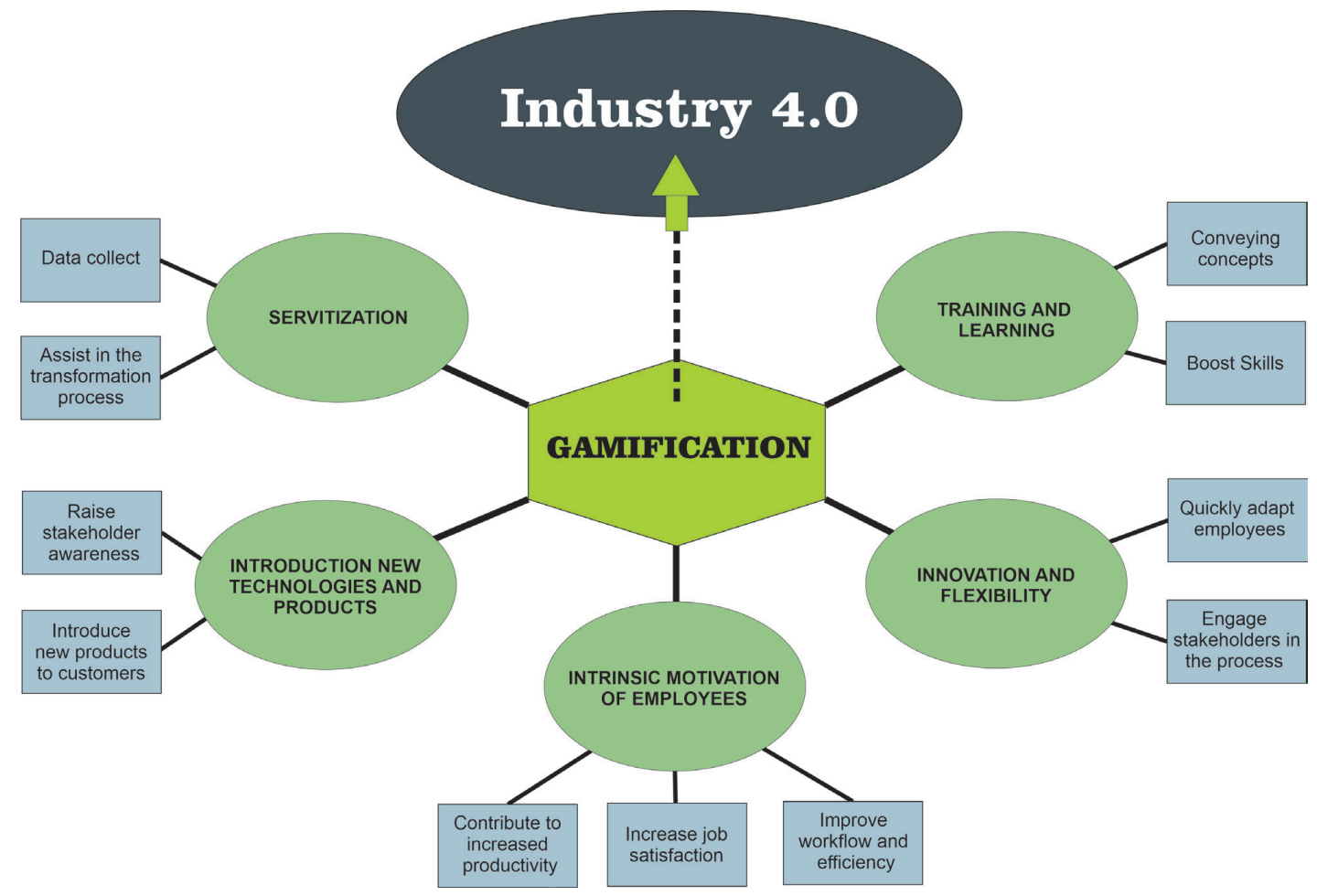

Figure 3. Perspectives on the usage of gamification in the Industry 4.0.

\section{Conclusions}

Through the analysis of the selected case studies on gamification in the industry, the game techniques used were identified, as well as their benefits and challenges. Gamification has also been shown to be adequate to support the development of Industry 4.0. Among the surveyed sample, the automobile industry was the one that applied Gamification the most.

Gamification has proven to be a powerful tool in this new industrial age because of its capacity to contribute to the intrinsic motivation of its stakeholders, thus impacting productivity, efficiency and job satisfaction. The simplification of complex ideas is also possible from this approach, contributing to effective learning, and the possibility of immersion in virtual situations for simulated decision making.

There is evidence that although the definition of Gamification is simple, its effective application in the industrial field is not immediate since there are many different variables and decisions that must be carefully considered and dealt with. For design and implementation, eleven aspects that need to be observed during application to ensure gamification success were found.

The research limitations include the hypothesis that many Gamification case studies may not be included in scientific databases, as many organizations do not turn the results of applying this approach into scientific studies.

For future research, a literature review that contemplates the use of complete games and not just game techniques, such as the Game-Based Learning (GBL) methodology, is the main suggestion (Subhash \& Cudney, 2018; Silva Júnior et al., 2019).

Another suggestion for future work, aiming at recognizing Gamification's potential in the industrial context, is to present a practical analysis of the use of game techniques, aiming at its better adaptation in terms of favoring the formation of engineers, the development of skills, and the improvement in training and interaction of stakeholders.

\section{References}

Alhammad, M. M., \& Moreno, A. M. (2018). Gamification in software engineering education: a systematic mapping. Journal of Systems and Software, 141, 131-150. http://dx.doi.org/10.1016/j.jss.2018.03.065.

Andrews, D., Dmitrijeva, J., Bigdeli, A. Z., \& Baines, T. (2018). Snakes and ladders in servitization: using a game to capture inhibitors and enablers of transformation. Research Technology Management, 61(6), 37-47. http://dx.doi.org/10.1080/08956308.2018.1516930. 
Andrews, D., Petridis, P., Baines, T., Ziaee Bigdeli, A., Shi, V. G., Baldwin, J., \& Ridgway, K. (2017). Gamification to engage manufacturers with servitization. In Advances in Manufacturing Technology XXXI: Proceedings of the 15th International Conference on Manufacturing Research, Incorporating the 32nd National Conference on Manufacturing Research (Vol. 5, pp. 195-200). London: University of Greenwich. http://doi.org/10.3233/978-1-61499-792-4-195.

Baena, F., Guarin, A., Mora, J., Sauza, J., \& Retat, S. (2017). Learning factory: the path to industry 4.0. Procedia Manufacturing, 9 , 73-80. http://dx.doi.org/10.1016/j.promfg.2017.04.022.

Bennett, R., \& Vijaygopal, R. (2018). Consumer attitudes towards electric vehicles: effects of product user stereotype and self-image congruence. European Journal of Marketing, 52(3-4), 499-527. http://dx.doi.org/10.1108/EJM-09-2016-0538.

Bigdeli, A. Z., \& Baines, T. (2017). Organisational transformation towards servitization. In Proceedings of the 6th Spring Servitization Conference (pp. 267-274). Birmingham: Aston Business School, Aston University.

Borrego, M., Foster, M. J., \& Froyd, J. E. (2014). Systematic literature reviews in engineering education and others developing interdisciplinary fields. Journal of Engineering Education, 103(1), 45-76. http://dx.doi.org/10.1002/jee.20038.

Bustinza, O. F., Bigdeli, A. Z., Baines, T., \& Elliot, C. (2015). Servitization and competitive advantage: the importance of organizational structure and value chain position. Research Technology Management, 58(5), 53-60. http://dx.doi.org/10.5437/08956308X5805354.

Cameron, J., \& Pierce, W. D. (1994). Reinforcement, reward, and intrinsic motivation: a meta-analysis. Review of Educational Research, 64(3), 363-423. http://dx.doi.org/10.3102/00346543064003363.

Cano, J. L., Lidon, 1., \& Rebollar, R. (2008). Learning Project Management through working for real clients. International Journal of Engineering Education, 24(6), 1199-1209.

Cano, J. L., Lidon, l., Rebollar, R., Roman, P., \& Saenz, M. J. (2006). Student groups solving real-life projects a case study of experiential learning. International Journal of Engineering Education, 22(6), 1252-1260.

Cerezo-Narváez, A., Córdoba-Roldán, A., Pastor-Fernández, A., Aguayo-González, F., Otero-Mateo, M., \& Ballesteros-Pérez, P. (2019). Training competences in industrial risk prevention with Lego ${ }^{\circledR}$ Serious Play ${ }^{\circledR}:$ a case study. Safety, 5(4), 81. http://dx.doi.org/10.3390/ safety5040081.

Dale, S. (2014). Gamification: making work fun, or making fun of work? Business Information Review, 31(2), 82-90. http://dx.doi. org/10.1177/0266382114538350.

Deshpande, A. A., \& Huang, S. H. (2011). Simulation games in engineering education: a state-of-the-art review. Computer Applications in Engineering Education, 19(3), 399-410. http://dx.doi.org/10.1002/cae.20323.

Despeisse, M. (2018). Teaching sustainability leadership in manufacturing : a reflection on the educational benefits of the board game Factory Heroes. Procedia CIRP, 69, 621-626. http://dx.doi.org/10.1016/j.procir.2017.11.130.

Deterding, S., Dixon, D., Khaled, R., \& Nacke, L. (2011a, September). From game design elements to gamefulness: defining gamification. In Proceedings of the 15th International Academic MindTrek Conference: Envisioning Future Media Environments (pp. 9-15). New York: ACM. http://dx.doi.org/10.1145/2181037.2181040.

Deterding, S., Khaled, R., Nacke, L. E., \& Dixon, D. (2011b). Gamification: toward a definition. In CHI Gamification Workshop Proceedings (pp. 12-15). Vancouver: ACM.

Donatiello, L., Morotti, E., Marfia, G., \& Di Vaio, S. (2018). Exploiting immersive virtual reality for fashion gamification. In Proceedings of the 2018 IEEE 29th Annual International Symposium on Personal, Indoor and Mobile Radio Communications (PIMRC) (pp. 1721). Piscataway: IEEE. http://doi.org/10.1109/PIMRC.2018.8581036.

Feltham, F., Vetere, F., \& Wensveen, S. (2007). Designing tangible artefacts for playful interactions and dialogues. In Proceedings of the 2007 Conference on Designing Pleasurable Products and Interfaces (pp. 61-75). New York: ACM. http://dx.doi.org/10.1145/1314161.1314167.

Fischer, T. C. (2017). Gamification and affordances: how do new affordances lead to gamification in a business intelligence system? Communications in Computer and Information Science, 748, 310-320. http://dx.doi.org/10.1007/978-3-319-64218-5_26.

Gebauer, H., \& Friedli, T. (2005). Behavioral implications of the transition process from products to services. Journal of Business and Industrial Marketing, 20(2), 70-78. http://dx.doi.org/10.1108/08858620510583669.

Gilotta, S., Spada, S., \& Ghibaudo, L. (2019). A technology corner for operator training in manufacturing tasks (Vol. 2). Cham: Springer International Publishing. http://dx.doi.org/10.1007/978-3-319-96071-5_96.

Günthner, W. A., Klevers, M., \& Sailer, M. (2015). Gamification in der Intralogistik: prozesse spielerisch verbessern. München: Technische Universität München.

Habash, R., \& Suurtamm, C. (2010). Engaging high school and engineering students: a multifaceted outreach program based on a mechatronics platform. IEEE Transactions on Education, 53(1), 136-143. http://dx.doi.org/10.1109/TE.2009.2025659.

Hauge, J. M. B., Stănescu, l. A., Carvalho, M. B., Stefan, A., Banica, M., \& Lim, T. (2015, August). Integrating gamification in mechanical engineering systems to support knowledge processes. In Proceedings of the ASME 2015 International Design Engineering Technical Conferences and Computers and Information in Engineering Conference. New York: American Society of Mechanical Engineers. http://doi.org/10.1115/DETC2015-47695.

Hauge, J. M. B., Wiesner, S., Stefan, 1. A., Stefan, A., \& Thoben, K. D. (2016, September). Applying gamification for developing formal knowledge models: challenges and requirements. In IFIP International Conference on Advances in Production Management Systems (pp. 713-720). Cham: Springer. http://doi.org/10.1007/978-3-319-51133-7_84.

Heeter, C., Lee, Y. H., Medler, B., \& Magerko, B. (2011, August). Beyond player types: gaming achievement goal. In ACM SIGGRAPH 2011 Game Papers (pp. 7). New York: ACM. http://doi.org/10.1145/2037692.2037701.

Hurst, W., Shone, N., Tully, D., Shi, Q., Chalmers, C., Hulse, J., \& O’Hare, D. (2019). Developing a productivity accelerator platform to support UK businesses in the industry 4.0 revolution. In Proceedings of the Third International Congress on Information and Communication Technology (pp. 517-525). Singapore: Springer. http://dx.doi.org/10.1007/978-981-13-1165-9_47.

Kampker, A., Deutskens, C., Deutschmann, K., Maue, A., \& Haunreiter, A. (2014). Increasing ramp-up performance by implementing the gamification approach. Procedia CIRP, 20, 74-80. http://dx.doi.org/10.1016/j.procir.2014.05.034.

Kapp, K. M. (2012). The gamification of learning and instruction: game-based methods and strategies for training and education. San Francisco: Pfeiffer. 
Korn, O., Muschick, P., \& Schmidt, A. (2017). Gamification of production? A study on the acceptance of gamified work processes in the automotive industry. In W. J. Chung \& C. S. Shin (Eds.), Advances in affective and pleasurable design (pp. 433-445). Cham: Springer. http://doi.org/10.1007/978-3-319-41661-8_42.

Leal, F., Martins, P. C., Torres, A. F., Queiroz, J. A., \& Montevechi, J. A. B. (2017). Learning lean with lego: developing and evaluating the efficacy of a serious game. Production, 27spe), e20162227. http://dx.doi.org/10.1590/0103-6513.222716.

Lee, J., Kim, J., Seo, K., Roh, S., Jung, C., Lee, H., Shin, J., Choi, G., \& Ryu, H. (2016). A case study in an automotive assembly line: exploring the design framework for manufacturing gamification. In C. Schlick \& S. Trzcieliński (Eds.), Advances in Ergonomics of Manufacturing: Managing the Enterprise of the Future (pp. 305-317). Cham: Springer. http://doi.org/10.1007/978-3-319-41697-7_27.

Leite, R. M. C., Costa, D. B., Morêda Neto, H. M., \& Durão, F. A. (2016). Gamification technique for supporting transparency on construction sites: a case study. Engineering, Construction, and Architectural Management, 23(6), 801-822. http://dx.doi.org/10.1108/ ECAM-12-2015-0196.

Lessel, P., Altmeyer, M., Müller, M., Wolff, C., \& Krüger, A. (2016, May). Don’t whip me with your games: investigating bottom-up gamification. In Proceedings of the 2016 CHl Conference on Human Factors in Computing Systems (pp. 2026-2037). New York: ACM. http://dx.doi.org/10.1145/2858036.2858463.

Lithoxoidou, E., Doumpoulakis, S., Tsakiris, A., Ziogou, C., Krinidis, S., Paliokas, 1., loannidis, D., Votis, K., Voutetakis, S., Elmasllari, E., \& Tzovaras, D. (2020). A novel social gamified collaboration platform enriched with shop-floor data and feedback for the improvement of the productivity, safety and engagement in factories. Computers \& Industrial Engineering, 139, 105691. http:// dx.doi.org/10.1016/j.cie.2019.02.005.

Liu, M., Huang, Y., \& Zhang, D. (2018). Gamification's impact on manufacturing: enhancing job motivation, satisfaction and operational performance with smartphone-based gamified job design. Human Factors and Ergonomics in Manufacturing \& Service Industries, 28(1), 38-51. http://dx.doi.org/10.1002/hfm.20723.

Mariano, A. M., \& Rocha, M. S. (2017). Revisão da literatura: apresentação de uma abordagem integradora. In XXVI Congreso Internacional AEDEM: Economy, Business and Uncertainty: Ideas for a European and Mediterranean Industrial Policy. Reggio Calabria, Italia: AEDEM International.

Marinho, M. T., Rodrigues, J. S., Zambon, K. L., \& Crepaldi, A. F. (2017). Distance learning for training business game tutors. Production, 27(spe), e20162218. http://dx.doi.org/10.1590/0103-6513.221816.

Markopoulos, A. P., Fragkou, A., Kasidiaris, P. D., \& Davim, J. P. (2015). Gamification in engineering education and professional training. International Journal of Mechanical Engineering Education, 43(2), 118-131. http://dx.doi.org/10.1177/0306419015591324.

Monchatre, S. (2007). From careers to itineraries... all the way through the notion of competence. Sociologie du Travail, 49(4), 472-488. http://dx.doi.org/10.1016/j.soctra.2007.09.007.

Morêda Neto, H., Leite, R. M., Costa, D. B., \& Durão, F. (2014). Visual communication panels for production control using gamification techniques. In Proceedings of the 22nd Annual Conference of the International Group for Lean Construction: Understanding and Improving Project Based Production. Oslo: 1GLC.

Müller, B. C., Reise, C., \& Seliger, G. (2015). Gamification in factory management education: a case study with Lego Mindstorms. Procedia CIRP, 26, 121-126. http://dx.doi.org/10.1016/j.procir.2014.07.056.

Müller, B. C., Reise, C., Duc, B. M., \& Seliger, G. (2016). Simulation-games for learning conducive workplaces: a case study for manual assembly. Procedia CIRP, 40, 353-358. http://dx.doi.org/10.1016/j.procir.2016.01.063.

Nicholson, S. (2012). A user-centered theoretical framework for meaningful gamification. In Proceedings of Games+Learning+Society (GLS) (Vol. 8). Madison: Games+Learning+Society.

Niesenhaus, J. (2013). Industry 4.0: gamification in the area of industrial production. Retrieved in 2019, July 26, from http://www. centigrade.de/blog/en/article/industry-4-0-gamification-in-the-area-of-industrial-production/

Niesenhaus, J. (2014). Gamification: Kritische Betrachtung in den Medien. Retrieved in 2019, July 26, from http://www.centigrade.de/ blog/de/article/gamification-kritischebetrachtung-in-den-medien/

Panthalookaran, V. (2018). Gamification of physics themes to nurture engineering professional and life skills. In Proceedings of the IEEE Global Engineering Education Conference (pp. 931-939). Piscataway: IEEE. http://dx.doi.org/10.1109/EDUCON.2018.8363330.

Paravizo, E., Chaim, O. C., Braatz, D., Muschard, B., \& Rozenfeld, H. (2018). Exploring gamification to support manufacturing education on industry 4.0 as an enabler for innovation and sustainability. Procedia Manufacturing, 21, 438-445. http://dx.doi.org/10.1016/j. promfg.2018.02.142.

Peterson, F., Hartmann, T., Fruchter, R., \& Fischer, M. (2011). Teaching construction project management with BIM support: experience and lessons learned. Automation in Construction, 20(2), 115-125. http://dx.doi.org/10.1016/j.autcon.2010.09.009.

Potente, T., Varandani, R., \& Prote, J. P. (2013). Gamification in management decisions: Judging global production networks in a cyberphysical way. Advanced Materials Research, 769, 327-334. http://dx.doi.org/10.4028/www.scientific.net/AMR.769.327.

Prince, M. J., \& Felder, R. M. (2006). Inductive teaching and learning methods: definitions, comparisons, and research base. Journal of Engineering Education, 95(2), 123-138. http://dx.doi.org/10.1002/j.2168-9830.2006.tb00884.x.

Reis, A. C. B., Barbalho, S. C. M., \& Zanette, A. C. D. (2017). A bibliometric and classification study of Project-based learning in Engineering Education. Production, 27(spe), e20162258. http://dx.doi.org/10.1590/0103-6513.225816.

Robson, K., Plangger, K., Kietzmann, J. H., McCarthy, 1., \& Pitt, L. (2016). Game on: engaging customers and employees through gamification. Business Horizons, 59(1), 29-36. http://dx.doi.org/10.1016/j.bushor.2015.08.002.

Roh, S., Seo, K., Lee, J., Kim, J., Ryu, H. B., Jung, C., Lee, H., \& Shin, J. (2016). Goal-based manufacturing gamification: bolt tightening work redesign in the automotive assembly line. In C. Schlick \& S. Trzcieliński (Eds.), Advances in ergonomics of manufacturing: managing the enterprise of the future (pp. 293-304). http://doi.org/10.1007/978-3-319-41697-7_26.

Sailer, M. (2016). Die wirkung von gamification auf motivation und leistung. Wiesbaden: Springer. http://dx.doi.org/10.1007/978-3658-14309-1. 
Sailer, M., Hense, J. U., Mayr, S. K., \& Mandl, H. (2017). How gamification motivates: an experimental study of the effects of specific game design elements on psychological need satisfaction. Computers in Human Behavior, 69, 371-380. http://dx.doi.org/10.1016/j. chb.2016.12.033.

Schlemmer, E., \& Marson, F. (2013, June). Immersive learning: metaversos e jogos digitais na educação. In Proceedings of the 8th Iberian Conference on Information Systems and Technologies (CISTI) (pp. 1-7). Piscataway: IEEE.

Schuldt, J., \& Friedemann, S. (2017). The challenges of gamification in the age of Industry 4. 0 focusing on man in future machine-driven working environments. In Proceedings of the 2017 IEEE Global Engineering Education Conference (pp. 1622-1630). Piscataway: IEEE. http://dx.doi.org/10.1109/EDUCON.2017.7943066.

Shi, V. G., Baines, T., Baldwin, J., Ridgway, K., Petridis, P., Bigdeli, A. Z., Uren, V., \& Andrews, D. (2017). Using gamification to transform the adoption of servitization. Industrial Marketing Management, 63, 82-91. http://dx.doi.org/10.1016/j.indmarman.2016.12.005.

Shyam Nivedhan, S., \& Priyadarshini, R. G. (2018). Gamification elements used in employee retention and enhancing employee productivity. IOP Conference Series: Materials Science and Engineering, 390(1), 12-39. http://dx.doi.org/10.1088/1757-899X/390/1/012039.

Silva Júnior, E., Reis, A. C. B., Mariano, A. M., Barros, L. B., Moysés, D. A., \& Silva, C. M. A. (2019). Systematic literature review of Gamification and Game-based Learning in the context of Problem and Project Based Learning approaches. In PAEE/ALE'2019: 11th International Symposium on Project Approaches in Engineering Education (PAEE) and 16th Active Learning in Engineering Education Workshop (ALE). Hammamet, Tunisia: PAEE Association.

Skinner, B. F. (1990). The behavior of organisms: an experimental analysis. Cambridge: BF Skinner Foundation.

Sousa, R. M., Stadnicka, D., Dinis-Carvalho, J., Ratnayake, R. M. C., \& lsoherranen, V. (2016). Gamification based lean knowledge dissemination: a case study. In Proceedings of the 2016 IEEE International Conference on Industrial Engineering and Engineering Management (pp. 164-168). Piscataway: IEEE. http://dx.doi.org/10.1109/1EEM.2016.7797857.

Subhash, S., \& Cudney, E. A. (2018). Gamified learning in higher education: a systematic review of the literature. Computers in Human Behavior, 87, 192-206. http://dx.doi.org/10.1016/j.chb.2018.05.028.

Taajamaa, V., Kirjavainen, S., Repokari, L., Sjöman, H., Utriainen, T., \& Salakoski, T. (2013). Dancing with Ambiguity Design thinking in interdisciplinary engineering education. In Proceedings of the 2013 IEEE Tsinghua International Design Management Symposium. Piscataway: IEEE. http://dx.doi.org/10.1109/TIDMS.2013.6981258.

Tran, N., \& Nathan, M. (2010). Pre-college engineering studies: An Investigation of the relationship between pre-college engineering studies and student achievenment in science and mathematics. Journal of Engineering Education, 92(2), 143-157. http://dx.doi. org/10.1002/j.2168-9830.2010.tb01051.x.

Tseng, T.-L. B., Akundi, A., Saavedra, J. A., \& Smith, E. D. (2016). A comparative study of teaching lean manufacturing via hands-on and computer-aided simulation. In Proceedings of the 2016 ASEE Annual Conference \& Exposition Proceedings. Washington: ASEE. http://dx.doi.org/10.18260/p.26281.

Vieira, E. S., \& Gomes, J. A. N. F. (2009). A comparison of Scopus and Web of Science for a typical university. Scientometrics, 81(2), 587-600. http://dx.doi.org/10.1007/s11192-009-2178-0.

Villagrasa, S., Fonseca, D., Redondo, E., \& Duran, J. (2014). Teaching case of gamification and visual technologies for education. Journal of Cases on Information Technology, 16(4), 38-57. http://dx.doi.org/10.4018/jcit.2014100104.

Wang, W. M., Wolter, L., Lindow, K., \& Stark, R. (2015). Graphical visualization of sustainable manufacturing aspects for knowledge transfer to public audience. Procedia CIRP, 26, 58-63. http://dx.doi.org/10.1016/j.procir.2014.07.032. 